University of Nebraska - Lincoln

DigitalCommons@University of Nebraska - Lincoln

1982

\title{
Uranium-series age of the Eel Point terrace, San Clemente Island, California
}

D. R. Muhs

University of Wisconsin, dmuhs@usgs.gov

B. J. Szabo

U.S. Geological Survey

Follow this and additional works at: https://digitalcommons.unl.edu/usgsstaffpub

Part of the Earth Sciences Commons

Muhs, D. R. and Szabo, B. J., "Uranium-series age of the Eel Point terrace, San Clemente Island, California" (1982). USGS Staff -- Published Research. 152.

https://digitalcommons.unl.edu/usgsstaffpub/152

This Article is brought to you for free and open access by the US Geological Survey at DigitalCommons@University of Nebraska - Lincoln. It has been accepted for inclusion in USGS Staff -- Published Research by an authorized administrator of DigitalCommons@University of Nebraska - Lincoln. 


\title{
Uranium-series age of the Eel Point terrace, San Clemente Island, California
}

\author{
D. R. Muhs \\ Department of Geography, University of Wisconsin, Madison, Wisconsin 53706 \\ B. J. Szabo \\ U.S. Geological Survey, Denver Federal Center, Denver, Colorado 80225
}

\begin{abstract}
Uranium-series analysis of the coral Allopora californica Verrill from the 2nd, 32-m Eel Point terrace on San Clemente Island, California, has yielded an age of $127,000 \pm 7,000 \mathrm{yr}$. The Eel Point terrace is thus correlative with numerous terrace localities on the southern California mainland, with coral reefs on Barbados and New Guinea dated about $120,000 \mathrm{yr}$, and with substage $5 \mathrm{e}$ of the marine oxygen-isotope record. A tectonic uplift rate of about $0.20 \mathrm{~m} / 1,000 \mathrm{yr}$ has been calculated assuming a sea level slightly higher than the present one at the time of terrace formation. Extrapolation of this uplift rate allows age estimates to be made for other terraces on the island.
\end{abstract}

\section{INTRODUCTION}

Emergent marine terraces are common along the coast of California and have been studied for many years. Age assignments for terraces are difficult because of the lack of datable material. The two techniques that have been used most often are amino acid racemization (Wehmiller and others, 1977; Wehmiller and Belknap, 1978; Kennedy, 1978; Lajoie and others, 1979; Muhs, 1979a, 1980; Karrow and Bada, 1980) and uranium-series dating. However, because amino acid racemization is a temperature-dependent reaction, ages
Figure 1. Location map of San Clemente Island and Eel Point fossil locality.

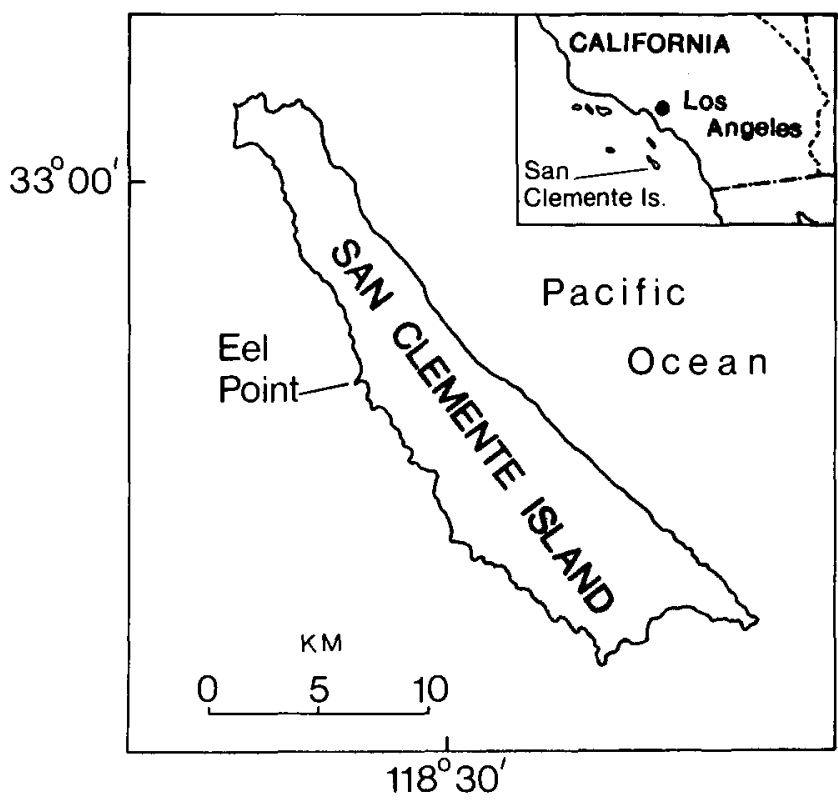

derived by kinetic models must be calibrated, preferably by radiometric methods. Uranium-series dating of mollusks has been attempted but has yielded discouraging results (Kaufmann and others, 1971); mollusks do not always act as closed systems with respect to the migration of uranium isotopes and their long-lived daughter products. Unrecrystallized fossil corals have proven to be the most reliable sample type for dating by the U-series method (Ku, 1976); however, corals are rare in California terrace deposits. Previously, U-series dates on corals from California have been obtained only for terraces near San Diego (Ku and Kern, 1974), Cayucos (Veeh and Valentine, 1967), and San Nicholas Island (Valentine and Veeh, 1969). With the exception of a $>200,000-y r$ date from the 9 th terrace on San Nicholas Island, these coral dates range from 100,000 to $140,000 \mathrm{yr}$ B.P.

Fragments of the hydrocoralline coral Allopora californica Verrill, 1866, were collected from the 2nd, 32-m Eel Point terrace, on the west coast of San Clemente Island (Fig. 1). This terrace is the broadest and topographically best expressed geomorphic surface on the island. We present 
TABLE 1. ISOTOPIC AND MINERALOGIC DATA FOR CORAL FRAGMENTS FROM EEL POINT, SAN CLEMENTE ISLAND, CALIFORNIA

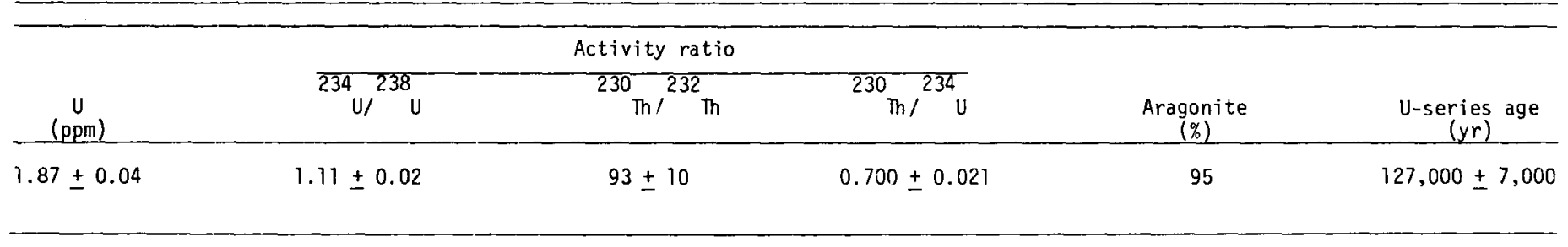

here the results of a uranium-series age estimate of these coral fragments.

\section{GEOLOGIC SETTING}

San Clemente Island is an uplifted fault block located about $100 \mathrm{~km}$ off the southern California coast (Fig. 1). The island is composed largely of Miocene andesite (Olmsted, 1958), with some sedimentary rocks. The eastern side of the island is a steep escarpment whose topographic expression is probably fault-related. The western side of the island is characterized by a remarkable flight of about 20 marine terraces, first noted by Lawson (1893) and Smith (1898). The southern half of the island remains to be studied in detail, but in a recent study (Muhs, 1980) of the Quaternary deposits on the northern half of the island, nine well-expressed terraces and two less well defined terraces were mapped.

Terrace deposits on San Clemente Island are generally thin $(<2 \mathrm{~m})$ and usually consist of rounded pebbles and cobbles with little matrix. A few fossil beds are present, most of which contain only one or two genera of mollusks, mainly Epilucina and Tegula. However, at Eel Point, an unusually fossiliferous terrace deposit was found, consisting of rounded andesite pebbles and cobbles cemented in places by calcium carbonate and overlain by dune sand. This deposit, on the 2nd terrace, contained Epilucina, Tegula, Haliotis, acmaeid limpets, barnacles, and echinoid plates and spines, all of which are generally indicative of a rocky, intertidal environment. In addition, fragments of the hydrocoralline coral Allopora californica Verrill were found. The modern range of this species is not known for certain but may extend from the Farallon Islands southward along the California coast and into the Gulf of California (Durham, 1947).

\section{URANIUM-SERIES DATING}

Chemical and analytical procedures used in $\mathrm{U}$-series dating have been described pre-

TABLE 2. UPLIFT RATES, SOUTHERN CALIFORNIA

\begin{tabular}{llll}
\hline Location & $\begin{array}{l}\text { Uplift rate } \\
(\mathrm{m} / 1000 \mathrm{yr})\end{array}$ & $\begin{array}{c}\text { Tectonic } \\
\text { style }\end{array}$ & \multicolumn{1}{c}{ Reference } \\
\hline San Clemente Island & $0.17-0.23$ & Strike-slip & This study \\
San Nicholas Island & $0.21-0.55$ & Strike-slip & Wehmiller and others, 1977 \\
Newport Beach & $0.15-0.20$ & Strike-slip & Wehmiller and others, 1977 \\
San Diego & $0.16-0.45$ & Strike-slip & Kern, 1977 \\
Goleta & 1.4 & Compressional Wehmiller and others, 1977 \\
Ventura & $4.0-10.0$ & Compressional Lajoie and others, 1979
\end{tabular}

viously (Szabo and Rosholt, 1969). The coral fragments were mechanically cleaned, crushed into small $(<2 \mathrm{~mm})$ pieces, scrubbed ultrasonically in distilled water, dried, and ground to a fine powder that was ashed for $8 \mathrm{~h}$ at $900^{\circ} \mathrm{C}$ to convert the $\mathrm{CaCO}_{3}$ to $\mathrm{CaO}$. The uranium concentration and the activity ratios of ${ }^{230} \mathrm{Th} /{ }^{234} \mathrm{U}$, ${ }^{234} \mathrm{U} /{ }^{238} \mathrm{U}$, and ${ }^{230} \mathrm{Th} /{ }^{232} \mathrm{Th}$ were determined by alpha-spectrometry measurements using a combined spike solution of ${ }^{236} \mathrm{U},{ }^{229} \mathrm{Th}$, and ${ }^{228} \mathrm{Th}$. The relative abundance of aragonite in the powder was determined by $\mathrm{X}$-ray diffraction analysis.

The calculated ${ }^{230} \mathrm{Th} /{ }^{234} \mathrm{U}$ age of the sample is $127,000 \pm 7,000 \mathrm{yr}$ (Table 1 ). The ${ }^{234} \mathrm{U} /{ }^{238} \mathrm{U}$ ratio of the sample is $1.11 \pm 0.02$; using the ${ }^{230} \mathrm{Th}$ age of $127,000 \mathrm{yr}$, the initial ${ }^{234} \mathrm{U} /{ }^{238} \mathrm{U}$ ratio is calculated to be $1.16 \pm$ 0.02 , close to the ${ }^{234} \mathrm{U} /{ }^{238} \mathrm{U}$ ratio in presentday seawater of $1.15 \pm 0.02$ (Szabo, 1969). The ${ }^{230} \mathrm{Th} /{ }^{232} \mathrm{Th}$ activity ratio is high $(93 \pm 10)$ and indicates no initial ${ }^{230}$ Th contamination in the sample.

\section{DISCUSSION}

The Eel Point terrace, with a U-series date of $127,000 \pm 7,000 \mathrm{yr}$ B.P. correlates with the Nestor terrace in San Diego (Useries age on coral of $120,000 \pm 10,000 \mathrm{yr}$;
$\mathrm{Ku}$ and Kern, 1974), Barbados terrace III (average age of 122,000 yr for eight determinations; Broecker and others, 1968), New Guinea terrace VIlb (estimated 125,000 yr; Veeh and Chappell, 1970; Bloom and others, 1974), and substage $5 \mathrm{e}$ of the marine oxygen-isotope record (123,000 yr; Shackleton and Opdyke, 1973). Substage 5e is thought to have been a time of unusually high sea level during the last (Sangamon or Riss-Würm) interglacial. Evidence from various Pacific islands away from active plate boundaries (Veeh, 1966; Ku and others, 1974; Szabo, 1979) suggests that sea level was 3 to $10 \mathrm{~m}$ higher 120,000 to $125,000 \mathrm{yr}$ ago than at present. This range of values, the present shoreline angle elevation of $32 \mathrm{~m}$ for the Eel Point terrace, and its age estimate of about 127,000 yr yield a tectonic uplift of 22 to $29 \mathrm{~m}$ and an uplift rate of 0.17 to 0.23 $\mathrm{m} / 1,000 \mathrm{yr}$. This rate of uplift is typical of areas in southern California that have experienced predominantly strike-slip tectonics but is much lower than that of areas presumed to have experienced compressional tectonics (Table 2).

The late Quaternary uplift rate derived from the Eel Point terrace can be used to estimate ages for other terraces on the 
TABLE 3. EXTRAPOLATED AGES OF OTHER TERRACES ON SAN CLEMENTE ISLAND AND TENTATIVE CORRELATIONS WITH THE MARINE OXYGEN ISOTOPE RECORD

\begin{tabular}{cccc}
\hline Terrace & $\begin{array}{c}\text { Elevation* } \\
(\mathrm{m})\end{array}$ & $\begin{array}{c}\text { Age estimate } \\
\left(10^{3} \mathrm{yr}\right)\end{array}$ & $\begin{array}{c}\text { Marine isotope } \\
\text { staget }\end{array}$ \\
\hline 1 & 5 & $90-100$ & $5 \mathrm{c}$ \\
3 & $40-53$ & $200-265$ & 7 \\
4 & $55-68$ & $275-340$ & 9 \\
5 & $75-92$ & $375-460$ & 11 \\
6 & $101-123$ & $505-615$ & 15 \\
7 & $140-160$ & $700-800$ & 19 or 21 \\
8 & $170-190$ & $850-950$ & $-\cdots$ \\
$8 \mathrm{a}^{5}$ & $190-210$ & $950-1050$ & $\cdots$ \\
9 & $220-240$ & $1100-1200$ & $-\cdots$ \\
$10^{5}$ & $250-300$ & $1250-1500$ & $-\cdots$ \\
\hline
\end{tabular}

*Elevation of shoreline angle, estimated from hand leveling or taken from $1: 4,000$ scale U.S. Navy topographic maps, contour interval = 10 feet $(3.1 \mathrm{~m})$; see Muhs $(1980)$.

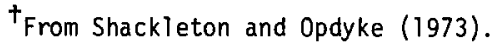

${ }^{5}$ Not well expressed geomorphically.

island and to make correlations with the marine oxygen-isotope record (Table 3 ). In calculating these age estimates, an assumption is made that sea level at the time of terrace formation was close to the present. This assumption was made by Bradley and Griggs (1976), in estimating older terrace ages near Santa Cruz, California, and by Chappell and Veeh (1978), in calculating ages for terraces on Atauro Island. The one exception to the assumption of sea level close to the present is for the lst terrace. The sea level curve of Bloom and others (1974) suggests that sea level at about 103,000 yr B.P. was about $-15 \mathrm{~m}$ and at about 82,000 yr B.P. was approximately $-13 \mathrm{~m}$ relative to the present. Since the $1 \mathrm{st}$ terrace is below the Eel Point terrace, it is younger than $127,000 \mathrm{yr}$ B.P., and it seems most likely that it is correlative with one of these two post-substage 5e high stands; therefore, its calculated ages are based on estimates of sea level at those times.

Certain of the terraces can be readily correlated with the marine oxygen-isotope record in this manner, but it is clear that there is less certainty with the oldest terraces (Table 3). The most reasonable correlations seem to be for the Ist terrace (about
100,000 yr B.P.; substage $5 \mathrm{c}$ ), the 3 rd terrace $(200,000$ to 265,000 yr B.P.; Stage 7$)$, the 4 th terrace $(275,000$ to 340,000 yr B.P.; Stage 9), and the 5 th terrace $(375,000$ to 460,000 yr B.P.; Stage 11). The lack of a terrace record corresponding closely to the oxygen-isotope curve before about 375,000 to $460,000 \mathrm{yr}$ B.P. may be the result of nonuniform uplift rates over time, an incorrect assumption about sea level at the time of terrace formation, or subsequent geomorphic activity. This latter factor could include both the destruction of terraces by seacliff retreat and the burial of marine terrace deposits by alluvial fan or colluvial deposits (Muhs, 1979b), causing several platforms to appear as one. A situation similar to that seen in the data of Table 3 was found by Chappell and Veeh (1978) on Atauro Island; these workers did not find coral reef terraces representing Stages 13 and 17 .

The U-series date for the Eel Point terrace is important for future marine terrace studies because it provides a calibration point for kinetic-model amino-acidracemization age estimates of terrace mollusks. Relative age assignments made for certain terraces on San Clemente Island
(Muhs, 1979a) can be combined with the $\mathrm{U}$-series date reported here to yield absolute age estimates (Muhs, in prep.).

\section{CONCLUSIONS}

Uranium-series dating of fossil hydrocoralline coral fragments from the 32-m Eel Point terrace on San Clemente Island has yielded an age of $127,000 \pm 7,000 \mathrm{yr}$. This age correlates the Eel Point terrace with a high stand of sea recorded on the southern California mainland, on Barbados and New Guinea, and in the marine oxygen-isotope record. The late Quaternary tectonic uplift rate on San Clemente Island is about $0.20 \mathrm{~m} / 1,000 \mathrm{yr}$, comparable to the rate for other areas in southern California that have experienced predominantly strike-slip tectonics. Extrapolation of this uplift rate allows age estimates to be made for other terraces on the island, but there is a close correspondence with the oxygen-isotope record for only the youngest of these terraces.

\section{REFERENCES CITED}

Bloom, A. L., Broecker, W. S., Chappell, J.M.A., Matthews, R. K., and Mesolella, K. J., 1974, Quaternary sea level fluctuations on a tectonic coast: New ${ }^{230} \mathrm{Th} /{ }^{234} \mathrm{U}$ dates from the Huon Peninsula, New Guinea: Quaternary Research, v. 4, p. 185-205.

Bradley, W. C., and Griggs, G. B., 1976, Form, genesis, and deformation of central California wave-cut platforms: Geological Society of America Bulletin, v. 87, p. 433-449.

Broecker, W. S., Thurber, D. L., Goddard, J., Ku, T. L., Matthews, R. K., and Mesolella, K. J., 1968, Milankovitch hypothesis supported by precise dating of coral reefs and deep-sea sediments: Science, v. 159, p. $297-300$.

Chappell, J., and Veeh, H. H., 1978, Late Quaternary tectonic movements and sea-level changes at Timor and Atauro lsland: Geological Society of America Bulletin, v. 89, p. $356-368$.

Durham, J. W., 1947, Corals from the Gulf of California and the north Pacific coast of America: Geological Society of America Memoir 20,68 p.

Karrow, P. F., and Bada, J. L., 1980, Amino acid racemization dating of Quaternary raised marine terraces in San Diego County, California: Geology, v. 8 , p. 200-204.

Kaufmann, A., Broecker, W. S., Ku, T. L., and Thurber, D. L., 1971, The status of U-series methods of mollusk dating: Geochimica et Cosmochimica Acta, v. 17, p. 1155-1183.

Kennedy, G. L., 1978, Pleistocene paleoecology, zoogeography and geochronology of marine invertebrate faunas of the Pacific Northwest coast (San Francisco Bay to Puget Sound) [Ph.D. thesis]: Davis, University of California, $824 \mathrm{p}$. 
Kern, J. P., 1977, Origin and history of upper: Pleistocene marine terraces, San Diego, California: Geological Society of America Bulletin, v. 88, p. 1553-1566.

$\mathrm{Ku}$, T. L., 1976, The uranium-series method of age determination: Annual Review of Earth and Planetary Sciences, v. 4, p. 347-379.

Ku, T. L., and Kern, J. P., 1974, Uranium-series age of the upper Pleistocene Nestor terrace, San Diego, California: Geological Society of America Bulletin, v. 85, p. 1713-1716.

$\mathrm{Ku}$, T. L., Kimmel, M. A., Easton, W. H., and O'Neil, T. J., 1974, Eustatic sea level 120,000 years ago on Oahu, Hawaii Science, v. 183, p. 959-962.

Lajoie, K. R., Kern, J. P., Wehmiller, J. F., Kennedy, G. L., Mathieson, S. A., SarnaWojcicki, A. M., Yerkes, R. F., and McCrory, P. F., 1979, Quaternary marine shorelines and crustal deformation, San Diego to Santa Barbara, California, in Abbott, P. L., ed., Geological excursions in the southern California area: San Diego, Calif., San Diego State University Department of Geological Sciences, p. 3-15.

Lawson, A. C., 1893, The post-Pliocene diastrophism of the coast of southern Cali. fornia: University of California Department of Geological Sciences Bulletin, v. 1, p. 115-160.

Muhs, D. R., 1979a, Marine terrace age assignments, uplift rates and sea level events on San Clemente Island, California: Geological Society of America Abstracts with Programs, v. 11, p. 484.

- 1979b, Geomorphic implications of late Quaternary paleosols on the Palos Verdes Peninsula, California: Geological Society of America Abstracts with Programs, v. 11, p. 297.

1980, Quaternary stratigraphy and soil development, San Clemente Island, California [Ph.D. thesis]: Boulder, University of Colorado, $221 \mathrm{p}$.
Olmsted, F. H., 1958, Geologic reconnaissance of San Clemente Island, California: U.S. Geological Survey Bulletin 1071-B, $68 \mathrm{p}$.

Shackleton, N. J., and Opdyke, N. D., 1973, Oxygen isotope and paleomagnetic stratigraphy of equatorial Pacific core V23-238: Oxygen isotope temperatures and ice volumes on a $10^{5}$ and $10^{6}$ year time scale: Quaternary Research, v. 3, p. 39-55.

Smith, W.S.T., 1898, A geological sketch of San Clemente Island: U.S. Geological Survey 18th Annual Report, Pt. II, p. 459-496.

Szabo, B. J., 1969, Uranium-series dating of Quaternary successions, in Ters, M., ed., Etudes sur le Quaternaire dans le monde: International Union for Quarternary Research Congress, 8th, p. 941-949.

_- 1979, Uranium-series age of coral reef growth on Rottnest Island, Western Australia: Marine Geology, v. 29, p. M11-M15.

Szabo, B. J., and Rosholt, J. N., 1969, Uraniumseries dating of Pleistocene molluscan shells from southern California-An open system model: Journal of Geophysical Research, v. 74, p. 3253-3260.

Valentine, J. W., and Veeh, H. H., 1969, Radiometric ages of Pleistocene terraces from San Nicholas Island, California: Geological Society of America Bulletin, v. 80, p. 1415-1418.

Veeh, H. H., 1966, Th ${ }^{230} / U^{238}$ and $U^{234} / U^{238}$ ages of Pleistocene high sea level stand: Journal of Geophysical Research, v. 71, p. 3379-3386.

Veeh, H. H., and Chappell, J., 1970, Astronomical theory of climatic change: Support from New Guinea: Science, v. 167, p. 862-865.
Veeh, H. H., and Valentine, J. W., 1967, Radiometric ages of Pleistocene fossils from Cayucos, California: Geological Society of America Bulletin, v. 78, p. 547-550.

Wehmiller, J. F., and Belknap, D. F., 1978 , Alternative kinetic models for the interpretation of amino acid enantiomeric ratios in Pleistocene mollusks: Examples from California, Washington and Florida: Quaternary Research, v. 9, p. 330-348.

Wehmiller, J. F., Lajoie, K. R., Kvenvolden, K. A., Peterson, E., Belknap, D. F., Kennedy, G. L., Addicott, W. O., Vedder, J. G., and Wright, R. W., 1977, Correlation and chronology of Pacific coast marine terrace deposits of continental United States by fossil amino acid stereochemistry: Technique evaluation, relative ages, kinetic model ages and geologic implications: U.S. Geological Survey Open-File Report 77 . $680,106 \mathrm{p}$.

\section{ACKNOWLEDGMENTS}

Reviewed by G. L. Kennedy and K. R. Lajoie.

MANUSCRIPT RECEIVED JUNE 8, 1981 REVISED MANUSCRIPT RECEIVED

SEPT. 2, 1981

MANUSCRIPT ACCEPTED OCT. 26, 1981 